Review of Income and Wealth

Series 52, Number 4, December 2006

\title{
WEALTH AND THE DISTRIBUTION OF INCOME: PERMANENT AND TRANSITORY EFFECTS
}

\author{
BY M. H. TUTTLE* \\ Sam Houston State University, Huntsville, Texas \\ AND \\ JeAn Gauger \\ University of Tennessee, Knoxville
}

\begin{abstract}
This paper examines the permanent and transitory effects of changes in wealth, the top federal marginal income tax rate, and capital gains tax rate on the distribution of Adjusted Gross Income (AGI). This paper establishes the importance of wealth in determining the distribution of AGI, and results here suggest that its effects can negate the permanent effect of a change in both tax rates. Of the two tax rates, the capital gains tax rate is the most important for AGI distribution. The marginal income tax rate is notably less important for long run behavior, but does have short run impacts.
\end{abstract}

\section{INTRODUCTION}

In the last twenty years, there have been five major changes in federal marginal income tax rates. Traditionally, a large portion of the debates leading up to these tax law changes center on the distributional impacts. One reason is that most of these statutory changes altered the marginal rate for the wealthiest households. Current tax debates center on taxation of the rich as well. In the 2004 presidential election, both candidates revived issues concerning taxation and its distributional impacts. John Kerry supported a repeal of the 2001 tax reductions for those in the upper income brackets (Petrecca, 2004). Repeal of the 2001 actions would return the top marginal income tax rate to 39.6 percent. The tax reductions enacted in 2001 were accelerated in 2003, and President Bush proposed to make all tax reductions permanent, including those for upper income earners (Klein, 2004).

This paper examines the impact of wealth and tax rates on the distribution of income, which is measured using Adjusted Gross Income (AGI). Here, the AGI distribution is measured as the share of income earned by the top 0.5 percent of households. This group reports a large share of total income and also pays a large share of income taxes. Feenberg and Poterba (2000) estimate that the top 0.5 percent of all income tax filers paid nearly one-fourth of all income taxes in 1995. Moreover, it is estimated that the top 1 percent of households paid 33.6 percent of all income taxes in 2000 and nearly 36 percent in 2001 (Joint Committee on

Note: The authors wish to thank Don Bruce, Mohammed Mohsin, Robert Bohm, Ronald Shrieves, and numerous conference and seminar participants for their helpful comments and suggestions. Any remaining errors are solely the authors' responsibility.

*Correspondence to: M. H. Tuttle, Department of Economics and International Business, 237A Smith-Hutson Building, Sam Houston State University, Huntsville, TX 77341, USA (mht001@, shsu.edu).

(C) 2006 The Authors

Journal compilation (C) 2006 International Association for Research in Income and Wealth Published by Blackwell Publishing, 9600 Garsington Road, Oxford OX4 2DQ, UK and 350 Main St, Malden, MA, 02148, USA. 
Taxation, 2000, 2001). Further, the wealthy report a large share of Adjusted Gross Income (AGI). ${ }^{1}$ For example, the share of income reported by the top 0.5 percent of income tax filers was 13.5 percent of all income in 1999. This group includes roughly 700,000 households that reported AGI in excess of an estimated $\$ 430,000$ in $1999 .^{2}$ Understanding the reporting behavior of the wealthy is important for policy makers when designing tax code changes, since they report such a large share of AGI and pay a large percentage of income taxes.

The importance of the wealthy in the U.S. tax system cannot be denied. What is questioned is how changes in tax rates impact the AGI distribution. Particularly, recent research investigates how the AGI distribution responds to changes in tax rates. Some have argued that tax rate changes have no permanent effect on the wealthiest households' reporting of income and, therefore, have limited distributional impacts, i.e. they suggest that any induced changes are solely temporary, or transitory, in nature, inducing no long-term effects. Others suggest permanent behavioral responses from tax rate changes. These changes can be due to altered tax avoidance behavior, tax evasion behavior, or change in work effort. Previous research findings also differ in the magnitude of these effects. Therefore, changes in the AGI distribution may be small or large, with estimated elasticities of income with respect to tax rate changes of zero, less than one, or greater than one; these changes may be temporary or permanent in nature. ${ }^{3}$

More recent research provides evidence that tax rate changes have permanent and transitory effects on the AGI distribution (Bruce et al., 2003). These transitory effects include shifting the realization of income by wealthier households into adjacent periods to take advantage of changing tax laws and therefore alter the AGI distribution. As Feenberg and Poterba (1993) note, the wealthiest households have greater opportunities to engage in such behavior. ${ }^{4}$ However, changing tax rates can also create permanent changes in the distribution of AGI. One possibility is the effect that changing tax rates may have on labor supplied by wealthy households. Also, changing tax rates can induce permanent changes in tax avoidance behavior. The current literature investigates this issue of temporary versus permanent changes in the AGI distribution from changes in the top marginal income tax and capital gains tax rates.

However, this paper argues that changes in wealth have substantial impacts on the AGI distribution. Feenberg and Poterba (1993) estimate the share of total capital gains reported by this group was greater than 50 percent by 1990 . Further, they show the capital gains share of total AGI hovering around 45 percent over most of the sample period. Piketty and Saez (2003) estimate the percentage of income from capital gains has increased for these households. The share of income from capital gains is volatile, but between 15 and 22 percent of reported income in

\footnotetext{
${ }^{1}$ Income in this paper refers to Adjusted Gross Income. AGI is the Internal Revenue Service's definition of income referring to gross income minus certain expenses.

${ }^{2}$ Estimate using Feenberg and Poterba's (1993) methodology. Calculations are available upon request from the author. Feenberg and Poterba (2000) adjust their AGI measure for changes in the treatment of capital gains.

${ }^{3}$ Here, permanent changes refer to long-lasting effects of changes in tax rates or wealth. Transitory changes refer to temporary effects of changes in tax rates or wealth.

${ }^{4}$ Examples include shifting of income payments from self-employment, delaying capital gains realizations, and engaging in legal tax avoidance.
} 
1998 came from capital gains. ${ }^{5}$ This share tends to increase moving up the income distribution. For example, Slemrod (2003) shows that capital gains comprised over 70 percent of income for the top 400 households.

Knowing that capital gains are an important source of income means the balance sheets of wealthy households must be considered as a possibly important source of income. During periods of rising assets values (and therefore rising wealth), the opportunity cost of current consumption, through the liquidation of assets, falls. Recent evidence by Davis and Palumbo (2001) and Mehra (2001) suggests that overall consumption increases during periods of increasing wealth. Thus, to increase consumption, these households may be more likely to realize capital gains during these periods of increasing wealth. Therefore, in periods of increasing wealth, like the late 1980s and 1990s, we should see increasing capital gains realizations. Holding all else constant, these realizations increase the share of AGI reported by the rich through the realization of capital gains and should have distributional impacts.

Given the importance of wealth for this group, the omission of wealth from the assessment can potentially bias the tax rate elasticities. In this paper, an estimate of the relationships between the AGI distribution and tax rates provides a baseline assessment. Measures of wealth are then added, to check for robustness in the tax rates and to demonstrate the importance of wealth for the AGI distribution.

The contributions of this paper are three-fold. First the importance of wealth in determining the distribution of income is confirmed. Further, this paper measures the permanent and transitory effects of wealth and tax rates changes on the AGI distribution. These permanent effects are estimated to uncover the permanent, or long-lasting, impacts of wealth and tax rate changes on the distribution of AGI. If a long run relationship exists, then this provides evidence that permanent distributional impacts exist. In addition to the long run effects, the transitory effects, or short run adjustments of the AGI distribution, are measured through an error correction model (ECM).

The results show that wealth has substantial impacts on the distribution of AGI, in the long run. The long run AGI distribution elasticity with respect to wealth is estimated at 0.57 to 0.62 . Further, the top capital gains tax rate is the most important tax rate for the AGI distribution, with an estimated elasticity between -0.42 and -0.46 . Therefore a permanent 10 percent increase in the top capital gains tax rate permanently reduces the share of AGI reported by the top 0.5 percent of households by 4.2 to 4.6 percent. The top federal marginal income tax rate is less important in influencing long run behavior. The estimated long run elasticity of the AGI distribution with respect to changes in the top federal marginal income tax rate is between 0.0 and -0.15 . These estimated long run tax rate elasticities are relatively consistent with previous research. ${ }^{6}$ Therefore, the effect of increases in wealth on the distribution of AGI can completely counter the effect of a simultaneous and equal percentage increase in both tax rates in the long run. The next

${ }^{5}$ This volatility supports the notion that the timing of capital gains realizations is important. Therefore, large, unexpected increases in the value of assets may have a positive impact on reported AGI in a given year.

${ }^{6}$ See Bruce et al. (2003). 
section presents the current debate and recent findings of tax rate effects on the distribution of AGI.

\section{Literature ReVIEW}

Feenberg and Poterba $(1993,2000)$ calculate the share of AGI reported by the top 0.5 percent of households. Their estimates are calculated using the Internal Revenue Service's Treasury Tax Model database and Statistics of Income (SOI). They suggest that portions of the movement in their distribution measure are due to permanent changes in reporting behavior, since sustained increases in AGI share exist following the large tax rate reductions in the 1980s. They agree that short-run shifting of income does occur, but there are also permanent effects from tax rate changes. Further, they note that the wealthy earn a large share of income from capital gains. Yet, when they adjust their measure to exclude capital gains realizations, their conclusions are unaltered - changes in taxes appear to permanently affect the distribution of AGI less capital gains.

Slemrod (1996) and Goolsbee (1999, 2000a, 2000b) suggest that changes in the AGI distribution (increases in the share of income reported by the top 0.5 percent of households) occur from income shifting, not permanent behavioral changes. Slemrod adjusts Feenberg and Poterba's measure to account for changes in the treatment of capital gains, and estimates a set of time series equations to measure the effect of tax rates. Since the exclusion of macroeconomic factors may bias results, Slemrod adds measures of wage inequality, real stock prices, and the corporate AAA bond rate. He includes the top marginal income tax rate and capital gains rate to estimate their influence on the AGI share. To control for timing effects, he adds leads and lags of changes in both tax rates. From his estimates, the capital gains rate plays a significant role in affecting the AGI distribution, while the effects of income tax rate changes are questionable. Both taxes reduce the share of income reported by the top 0.5 percent of households. Goolsbee (1999) looks at several tax rate changes and concludes the historical responsiveness of the rich is small, and that results from the 1980s are "atypical." Goolsbee (2000a, 2000b) estimates the absolute value of the elasticity of taxable income to the income tax rate to be between 0.0 and -0.4 . He concludes, like Slemrod, that the majority of the effects from tax rate changes occur from changes in the timing of the reporting of income (from labor or capital gains), not from permanent changes in behavior.

Bruce et al. (2003) estimate AGI distribution elasticities from income and capital gains tax changes. They control for various economic factors, such as real GDP growth, productivity, globalization, and schooling. Like Slemrod, the authors also allow for timing effects by adding lead and lag changes of both tax rates. They estimate the AGI distribution elasticity with respect to changes in the top capital gains tax rate between -0.41 and -0.51 . Marginal income tax rates have a smaller effect upon the share of income reported, with an estimated elasticity between -0.27 and -0.31 . These findings represent permanent changes and are robust when controlling for various economic factors. Using dynamic time series analysis, they conclude that the major determinants of the distribution of AGI are changes in the capital gains rate and macroeconomic factors. They find a long-run, 
permanent relationship between the AGI share, the top federal marginal income tax rate, the top capital gains tax rate, and macroeconomic factors. The respective tax rates have a negative effect on the share of AGI reported by the top 0.5 percent of households, while output has a large positive effect and interest rates induce a negative response. Their research goes a long way in showing that tax rates and macroeconomic factors induce permanent changes in the top AGI share.

The possibility exists that a long run model containing only tax rates omits relevant factors that determine the AGI distribution, namely household wealth. If altering tax rates truly changes labor decisions among the wealthy, then omitting wealth may bias the income tax rate and capital gains tax rate elasticities. If an increase in the top marginal income tax rate or capital gains tax rate creates a substitution effect between labor decisions and the realization of capital gains or savings, then increases in the top capital gains rate may reduce capital gains realizations, causing an increase in net wealth, or it could change current savings behavior. Therefore, omitting wealth measures from an analysis can bias either of the tax rate elasticities, attributing a larger or smaller effect between income tax rate or capital gains rate changes and the AGI distribution. Therefore, measures of real wealth will be added to address this issue. However, if wealth has only transitory effects, then we should find no significant long run relationship between the wealth measures and the AGI share. The tax rate elasticities should be robust. In such a case, wealth should be included in a short run model only.

Further, wealth can impact income through realizations of capital gains (liquidation of assets) to fund current consumption. The wealth effect in consumption might tend to increase current period AGI. Since the wealthy own the largest share of wealth, these increases in wealth may have distributional impacts by increasing the AGI reported by these wealthy households faster than AGI reported by all other households. Therefore, increases in wealth may potentially impact the distribution of AGI.

Due to data availability issues, aggregate net wealth variables are used rather than net wealth of the top 0.5 percent of households; real net wealth is included as a proxy. The use of a proxy that is not highly correlated with the true variable can cause biased and inefficient parameters. However, these deficiencies get smaller the greater the correlation between the two measures. Although aggregate wealth is not perfectly positively correlated with real wealth of the household sector in question, it should be highly correlated, since rich households hold a large share of aggregate wealth. ${ }^{7}$

\section{Empirical Methods and Data}

As mentioned in the last section, previous research presents various estimates of the response of the AGI distribution to changes in tax rates. The contribution of this paper is to provide further insight into the behavior of the AGI distribution. Not only are long-run tax rate elasticities measured, but also short-run elasticities and the duration of these responses are estimated.

${ }^{7}$ In the summary of the 1998 Survey of Consumer Finances, Kennickell et al. (1998) note that income and wealth are positively correlated. Further, mean wealth for top income earners is correlated with changes in average aggregate wealth. 
The method employed here to measure the permanent impacts from changing wealth and tax rates on the income distribution is a Dynamic OLS (DOLS), as suggested by Stock and Watson (1993), which is a single-equation cointegration technique. The cointegrating equation is a single equation, and takes the following form:

$$
\mathrm{LnAGI}_{\mathrm{t}}=\beta_{0}+\beta_{1} \mathrm{LnCG}_{\mathrm{t}}+\beta_{2} \mathrm{LnIT}_{\mathrm{t}}+\beta_{3} \mathrm{LnW}_{\mathrm{t}}+\mathrm{X} \alpha^{\prime}+\omega_{\mathrm{t}}
$$

where $\mathrm{AGI}_{\mathrm{t}}$ is the distribution measure used (share of income reported by the top 0.5 percent of tax filers), $\mathrm{CG}_{\mathrm{t}}$ is the top federal capital gains tax rate, $\mathrm{IT}_{\mathrm{t}}$ is the top federal marginal income tax rate, and $\mathrm{W}_{\mathrm{t}}$ represents the wealth series added to equation (1). All variables are included in natural logs. X denotes a matrix of the lead, lag, and current values of the first differences of the natural log of each right-hand side variable in the cointegrating equation. Further, since all variables are in natural logs, the parameters yield measures of elasticity.

It is reasonable to assume that these same variables have immediate impacts upon the distribution of AGI, but these short-run influences are not necessarily identical to any long-term impacts. Therefore, a two-step estimation process is called for, where the second stage is a model of the short-run responses. Therefore, once the long-run relationship is estimated, a short-run dynamic model in the form of an error correction model (ECM) is employed, and is shown in equation (2). All variables in equation (2) are as previously noted and are included in the first differences of natural logs, except for the error correction term (ECT).

$$
\text { (2) } \Delta \mathrm{AGI}_{\mathrm{t}}=\alpha_{0}+\alpha_{1} \Delta \mathrm{AGI}_{\mathrm{t}-1}+\alpha_{2} \Delta \mathrm{CG}_{\mathrm{t}-1}+\alpha_{3} \Delta \mathrm{IT}_{\mathrm{t}-1}+\alpha_{4} \Delta \mathrm{W}_{\mathrm{t}-1}+\alpha_{5} \mathrm{ECT}_{\mathrm{t}-1}+\eta_{\mathrm{t}}
$$

The ECM uncovers short run responses of the AGI share and speed of adjustment to the new long run equilibrium. This new long run equilibrium arises from changes in the right-hand side variables in the cointegrating relationship (equation (1)) at time $\mathrm{t}-1$. The disequilibrium that exists at time $t$ from a change in the long run relationship at time $t-1$ is given by the lagged value of the error correction term (ECT). Therefore, this two-step method captures the long run and short run dynamics of the AGI distribution.

The ultimate purpose is to differentiate between permanent changes in the distribution of AGI and transitory effects. If any permanent responses exist, then empirical results should confirm the existence of a cointegrating relationship. Specifically, residual-based cointegration tests are employed, and the estimate of $\alpha_{7}$ should lie in the interval $(-1,0)$ and be statistically significant. The short-run elasticities from the ECM give some insight into the short-run, transitory effects.

The primary source for the AGI series is Feenberg and Poterba (2000), and is available for the years 1960 through $1996 .{ }^{8}$ This series is supplemented through 1999 using the methodology described in Feenberg and Poterba (1993). The Statistics of Income Bulletin (Internal Revenue Service Statistics of Income Division, 2000-2001) provides the data needed to supplement the AGI series, and interpolation is used to fill in the two missing observations in the 1960s.

\footnotetext{
${ }^{8}$ The data series is available at http://www.nber.org/ taxsim.
} 


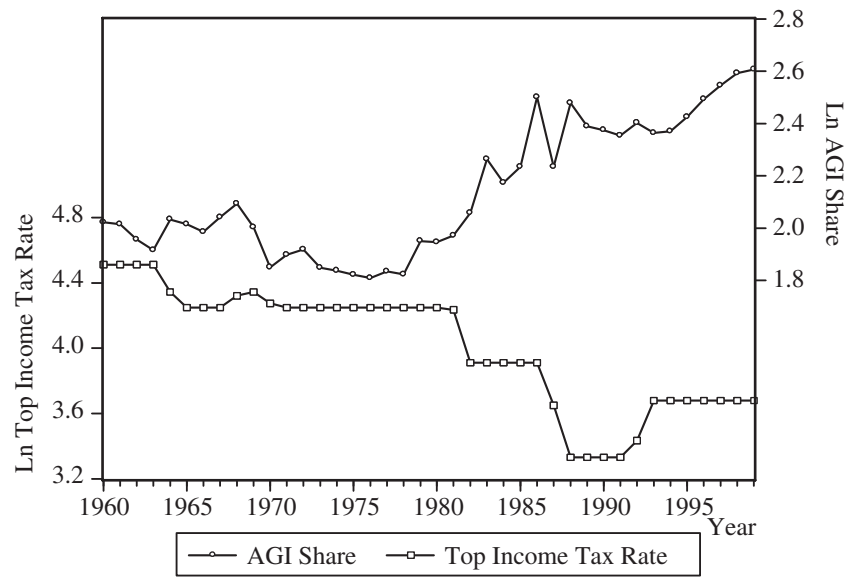

Figure 1a. Top AGI Share and Top Income Tax Rate-1960-1999

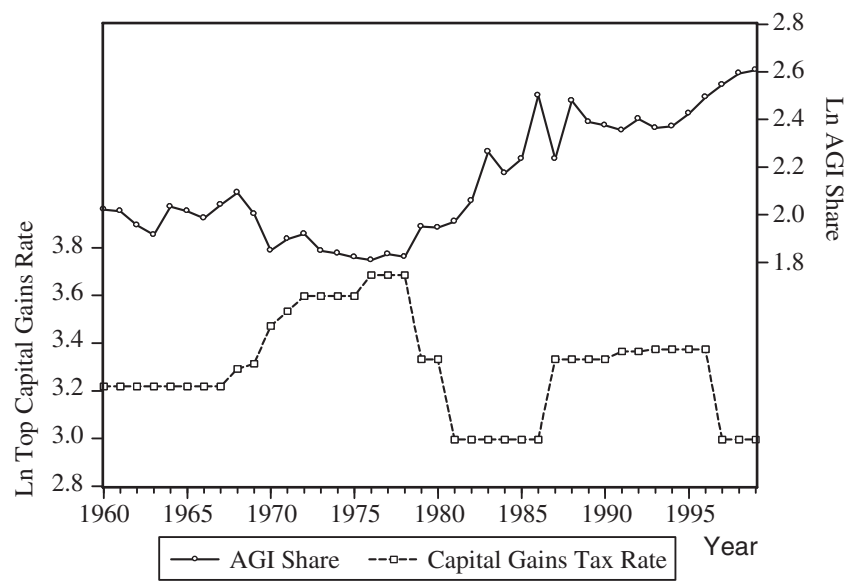

Figure 1b. Top AGI Share and Capital Gains Rate-1960-1999

Figures $1 \mathrm{a}$ and $1 \mathrm{~b}$ are graphs of the individual tax rate and AGI distribution series. ${ }^{9}$ These graphs provide some interesting insights. Figure 1a displays the AGI distribution and top marginal income tax rate. There have been five major changes in the top marginal income tax rate since 1960. The first three changes in 1964, 1982, and 1987 are marginal rate decreases, while those of 1992 and 1993 are rate increases. In fact, the historical movement in this rate has been generally downward through 1991, and rising after this date until the recent tax code changes. From the figure, it appears that rate decreases in the early 1960s and 1980s are associated with increases share of income of the top 0.5 percent (therefore, more AGI reported by the top 0.5 percent of households). Rate increases in the $1990 \mathrm{~s}$,

${ }^{9}$ Measured as the share (or percent) of AGI reported by the top 0.5 percent of households. 
however, do not seem to be followed by decreases in the share of income of the top 0.5 percent.

The evidence concerning the relationship between the distribution of AGI and capital gains tax rate is less ambiguous. Large increases in the capital gains rate around 1970 and in 1986 are followed by large downward swings in the share of AGI reported by the top 0.5 percent of households, as shown in Figure $1 \mathrm{~b}$. The top AGI share trends upward in the 1980s and late 1990s, following the decline in capital gains tax rates in 1979 and 1997. On the other hand, tax increases in the 1970s coincide with decreases in the AGI distribution. Therefore, the circumstantial evidence suggests the importance of the capital gains tax rate over the marginal income tax rate, but closer evaluation is warranted.

Two series were collected to control for the financial position of the wealthiest individuals. Aggregate wealth data are provided in the Federal Reserve's Balance Sheet of the United States (Board of Governors of the Federal Reserve, 2001) from the Flow of Funds Accounts. ${ }^{10}$ Net worth is adjusted by the GDP deflator to derive real net worth (RW). ${ }^{11}$ Additionally, this variable is adjusted for population growth, to better match the indexing of the AGI series. Another measure of real wealth is also used. This second measure is real wealth less housing wealth (RWH), and is measured as net wealth minus the aggregate value of housing assets plus the value of mortgages. This is used to attempt to better measure the concentration of wealth among the richest households, since housing is a small portion of their wealth. ${ }^{12}$ Finally, wealth is measured as beginning-of-period levels, since the net wealth variables are lagged one period.

Figures 1c and 1d show the distribution of AGI and, respectively, each measure of wealth. Although both measures of wealth trend upwards through the entire sample period, the majority of the growth takes place after 1986. In fact, the largest periods of growth correspond with the largest increases in the AGI share. Therefore, there appears to be some positive relationship between the two measures of aggregate wealth and the share of income reported by the wealthiest households.

By now, the potential perils of using time series data are well established. Non-stationary data can produce spurious results, intimating statistical relationships that simply do not exist. Fortunately, methods exist to test for nonstationarity and control for the difficulties presented, such as employing DOLS and an ECM. To test the stochastic properties of the variables, Augmented Dickey-Fuller Tests (ADF) are estimated (Dickey and Fuller, 1981). Further, a second unit root test, the KPSS test, is employed, which tests the null of stationarity (Kwiatkowski et al., 1992). Also, the possibility exists that the two-stage estimation may not be appropriate. If all variables are stationary in levels, then the behavior of the top AGI share can be modeled using a single equation approach.

\footnotetext{
${ }^{10}$ Specifically, net wealth is from Table B.100 from the Flow of Funds Accounts. This series includes wealth of the non-profit sector. As noted, this measure serves as a proxy, since we do not have access to any data that allows measurement of the actual wealth share for the top 0.5 percent of households.

${ }^{11}$ We chose the GDP deflator, since it is the broadest measure of price changes available.

${ }^{12}$ Poterba (2000) and Poterba and Samwick (1995) report that approximately 6-10 percent of housing wealth is owned by households at the top of the distribution (top $0.5 \%$ ).
} 


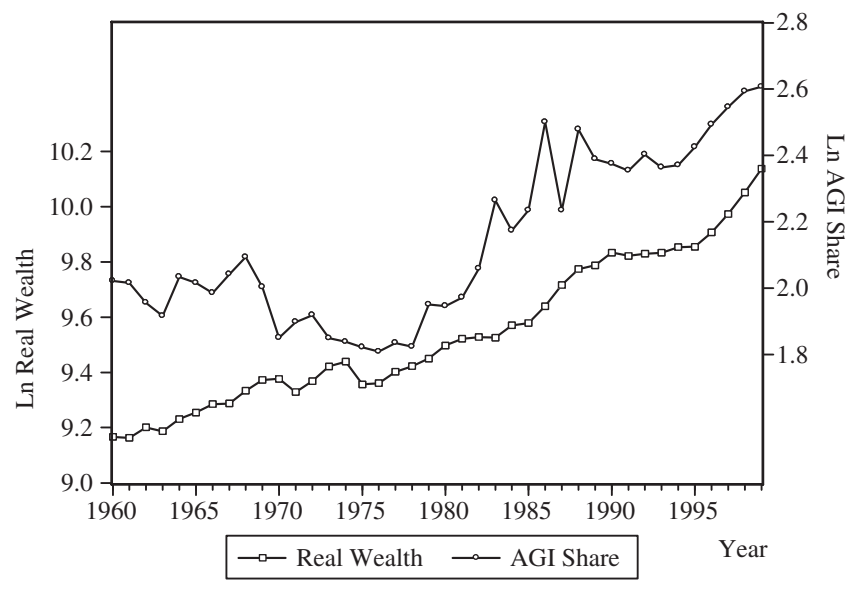

Figure 1c. Top AGI Share and Real Wealth-1960-1999

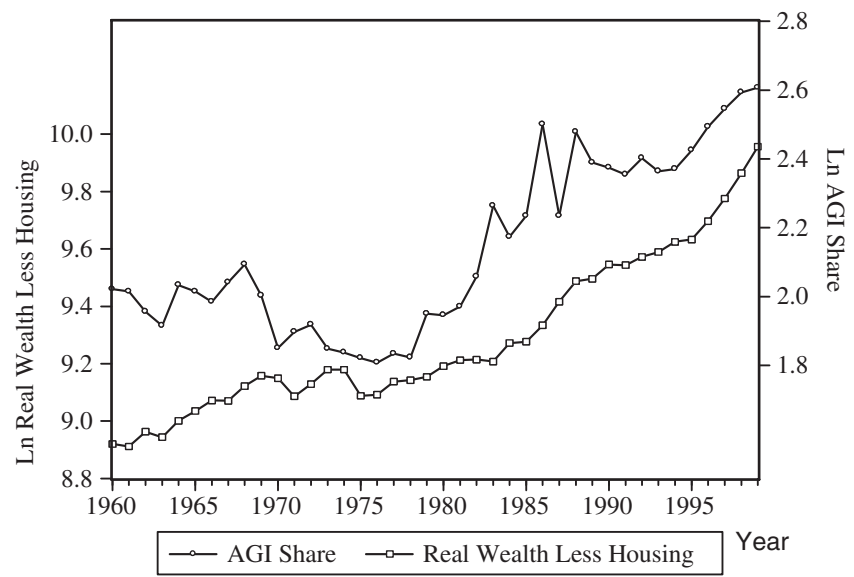

Figure 1d. Top AGI Share and Real Wealth Less Housing Wealth-1960-1999

A constant and time trend is included in the ADF and KPSS tests for each variable. The results of the ADF tests in levels are presented in Table $1 .{ }^{13}$ From Panel A of Table 1, all variables appear non-stationary, and they are at least integrated of order one. Thus, estimating a model using levels of the variables will provide spurious results if they do not share a long run relationship (i.e. they are not cointegrated).

A second round of ADF and KPSS tests is estimated for the first differences of all variables, using one lag in the specification. The purpose is to identify if all variables are I(1) or I(2). These results are contained in Panel B of Table 1. Indeed, all variables appear to be I(1), so all of the variables are stationary in firstdifferences. Therefore, if the variables are not cointegrated, then using OLS can

${ }^{13} \mathrm{~A}$ lag length of one is used. 
TABLE 1

UNIT RoOt TeSts

\begin{tabular}{|c|c|c|c|c|}
\hline \multirow[b]{2}{*}{ Series } & \multicolumn{2}{|c|}{ Augmented Dickey-Fuller Test } & \multicolumn{2}{|c|}{ KPSS Test } \\
\hline & Test Statistic & $5 \%$ MacKinnon C.V. & Test Statistic & $5 \%$ C.V. \\
\hline \multicolumn{5}{|c|}{ Panel A: Variables in levels } \\
\hline AGI & -1.64 & -3.53 & 0.38 & 0.146 \\
\hline $\mathrm{CG}$ & -1.75 & -3.53 & 0.16 & 0.146 \\
\hline IT & -2.32 & -3.53 & 0.16 & 0.146 \\
\hline RW & -1.05 & -3.53 & 0.35 & 0.146 \\
\hline RWH & 0.07 & -3.53 & 0.42 & 0.146 \\
\hline \multicolumn{5}{|c|}{ Panel B: Variables in first-differences } \\
\hline$\Delta \mathrm{AGI}$ & -5.97 & -3.53 & 0.07 & 0.146 \\
\hline$\Delta \mathrm{CG}$ & $-3.16^{*}$ & -3.53 & 0.08 & 0.146 \\
\hline$\Delta \mathrm{IT}$ & -4.08 & -3.53 & 0.08 & 0.146 \\
\hline$\Delta \mathrm{RW}$ & -4.07 & -3.53 & 0.06 & 0.146 \\
\hline$\Delta \mathrm{RWH}$ & -4.14 & -3.53 & 0.11 & 0.146 \\
\hline
\end{tabular}

Note: *Null hypothesis rejected at a $90 \%$ level of confidence.

TABLE 2

COINTEGRATION EQUATIONS

\begin{tabular}{|c|c|c|c|}
\hline & Specification A & Specification B & Specification $\mathrm{C}$ \\
\hline Variable & Long Run Elasticity & Long Run Elasticity & Long Run Elasticity \\
\hline Constant & $\mathbf{5 . 9 9 6}(0.475)$ & $-1.860(2.169)$ & $-1.231(1.221)$ \\
\hline Capital gains rate & $\mathbf{- 0 . 5 0 3}(0.139)$ & $-0.464(0.151)$ & $\mathbf{- 0 . 4 2 4}(0.112)$ \\
\hline Income tax rate & $-\mathbf{0 . 5 4 7}(0.068)$ & $-0.113(0.088)$ & $\mathbf{- 0 . 1 4 7}(0.049)$ \\
\hline Real wealth & - & $0.624(0.188)$ & - \\
\hline Real wealth minus housing & - & - & $\mathbf{0 . 5 7 4}(0.109)$ \\
\hline Schwarz criteria & -1.141 & -1.608 & -1.899 \\
\hline Adjusted $\mathrm{R}^{2}$ & 0.835 & 0.918 & 0.939 \\
\hline Jarque-Bera (p-value) & 0.849 & 0.829 & 0.904 \\
\hline Cointegration test & -3.128 & -3.587 & -3.958 \\
\hline
\end{tabular}

Notes: Standard errors in parenthesis.

Critical values for cointegration test are -3.966 at the 95 percent level of confidence and -3.614 at the 90 percent level of confidence.

result in spurious estimation. On the other hand, if these variables are cointegrated, as was the case in Bruce et al. (2003), then spurious estimates are no longer a problem.

\section{EMPIRICAL Results}

To estimate the permanent effect of tax rate changes on the AGI share, equation (1) is estimated. ${ }^{14}$ The results are provided in Table 2. The first specification, Specification A, restricts $\beta_{3}$ (the wealth parameter) to zero and serves as a baseline estimate only. Next, Specifications B and C add measures of wealth to demonstrate their importance in determining the distribution of AGI.

\footnotetext{
${ }^{14}$ The Newey-West (1987) method is applied.
} 
Specification A provides some interesting results. First, using tax rates only provides estimates that are relatively robust to findings in the previous literature. However, tests fail to indicate a long run relationship between the variables. The elasticity of AGI share with regard to both tax rates is between -0.50 and -0.55 , with the top marginal income tax rate elasticity being slightly higher than that of the capital gains tax rate.

As noted, certain omitted variables may bias the tax rate elasticities. The amount of wealth held by the wealthiest households can serve as a source of capital gain income. ${ }^{15}$ If income tax rates are high enough, the households considered here can substitute capital gains realizations for labor earnings, thus creating a substitution effect. They can also reallocate earnings from forms taxable as income to those forms taxed at the capital gains rate. Thus if income tax rates are high enough, these households can draw upon their net wealth to take advantage of lower capital gains tax rates. Therefore, the top marginal income tax rate and wealth should be negatively correlated. Indeed, the measures are negatively correlated, with respective measures of $\rho=-0.83$ and $\rho=-0.85$. The relationship between wealth and the income tax rate indicates that the exclusion of wealth will bias the top marginal income tax rate elasticity downward. This will result in a larger income tax rate elasticity, in absolute value, if wealth is omitted from the analysis. On the other hand, the capital gains rate and wealth measures are also negatively correlated, but the correlation is smaller $(-0.13$ to -0.24$)$ than the correlation between the wealth measures and the top marginal income tax rate. Therefore, the effect of wealth on the capital gains rate elasticity is likely to be smaller. Further, they may also realize wealth based purely upon the wealth effect, i.e. for consumption purposes only. As noted, previous research identifies a positive relationship between wealth and consumption. Therefore, increases in wealth can lead to greater liquidation of wealth, which increases the share of AGI reported by the wealthiest households.

As results in Table 2 show, when aggregate real wealth is added (Specification B), the estimate of the long run income tax elasticity falls notably (from -0.547 to -0.113 ) and is statistically insignificant. The exclusion of wealth from an analysis appears to severely bias the long run income tax rate elasticity. The capital gains elasticity, however, appears robust. In fact, this estimated elasticity is close to results found in previous work (Bruce et al., 2003). Evidence here indicates that the capital gains rate has a substantial impact on the distribution of AGI, while the income tax rate plays no statistical role in the long run in this specification.

Evidence indicates that real wealth plays an economically and statistically significant role in determining AGI share in the long run. The permanent effect of a wealth change is larger (in absolute value) than the effect of either tax rate. Thus, as suspected, wealth appears to be an important determinant. Its exclusion results in substantial bias in the income tax rate elasticity.

\footnotetext{
${ }^{15}$ There are other important sources of income for this group beyond capital gains realizations. For these households, capital gains do serve as one important source of income. Large increases in wealth may induce greater realization of capital gains and increase the share of total income reported by this group. Indeed, the reporting of capital gains realizations is one of the more volatile income categories reported by these households.
} 
TABLE 3

ERror-CORRECTION MODELS

\begin{tabular}{lcr}
\hline \hline & Specification B2 & Specification C2 \\
\cline { 2 - 3 } Variable & Parameter Estimate & Parameter Estimate \\
\hline$\Delta$ Capital gains rate last year & $0.023(0.101)$ & $0.039(0.098)$ \\
$\Delta$ Income tax rate last year & $-\mathbf{0 . 2 5 8} \mathbf{( 0 . 0 7 4 )}$ & $\mathbf{- 0 . 2 5 2}(\mathbf{0 . 0 8 2})$ \\
$\Delta$ AGI distribution last year & $-0.305(0.153)$ & $-0.251(0.147)$ \\
$\Delta$ Wealth last year & $-0.429(0.342)$ & - \\
$\Delta$ Wealth less housing last year & - & $-0.234(0.242)$ \\
Adjustment parameter & $\mathbf{- 0 . 4 4 8}(\mathbf{0 . 1 8 2})$ & $\mathbf{- 0 . 5 1 7}(\mathbf{0 . 1 9 3})$ \\
Constant & $0.037(0.019)$ & $0.036(0.020)$ \\
Adjusted R & 0.349 & 0.332 \\
\hline
\end{tabular}

Notes: Bold indicates significance at the $95 \%$ level of confidence. Italics indicates significance at the $90 \%$ level of confidence. Standard errors in parenthesis.

Newey-West (1987) method applied.

Next, Specification $\mathrm{C}$ adjusts the real net wealth variable by removing housing equity. As with the previous specification, the long run capital gains rate elasticity is relatively robust. However, it is immediately apparent that removing housing wealth has substantial impacts on the parameter estimate for the marginal income tax rate and its significance. The income tax rate in this specification is statistically significant, but it still plays an economically limited role in determining the distribution of AGI in the long run. Additionally, this measure of long run wealth has a significant role in determining the AGI distribution, but the parameter is slightly smaller. In this specification, the wealth parameter is equal, in absolute value, to the sum of the top marginal income tax and capital gains tax rate parameters. Therefore, a percentage change in real wealth that exactly equals a given percentage change in both tax rates will have equal offsetting impacts on the distribution of AGI in the long run.

The pattern of short run, transitory responses is very different. ECM Specification B2 in Table 3 includes the lagged first difference of total real wealth, top tax rates, and AGI distribution. This is the short run model for the long run Specification B in Table 2. ${ }^{16}$ In this specification, there is a significant and negative effect from a change in the top marginal income tax rate, as seen by the parameter $(-0.258)$ on the lagged top marginal income tax rate change. Yet, the effect of a change in the capital gains rate has a statistically and economically insignificant effect on the AGI distribution in the short run. Thus, income tax rate changes have a short run impact on the AGI distribution in this specification, while capital gains rate changes have a larger effect over a longer period of time. ${ }^{17}$ Specifically, a 1 percent increase in the top marginal income tax rate creates a reduction in the share of income earned by the top 0.5 percent of households by 0.258 percent in the following year. An equal percentage increase in the capital gains rate would ultimately decrease the AGI measure by 0.464 percent. Yet, this process takes

\footnotetext{
${ }^{16}$ Test results fail to reject the null of weak and strong exogeneity of both tax rates and wealth.

${ }^{17}$ Recall that the long income tax parameter is statistically zero in Specification B in Table 2.
} 
several years, since it works through the long run adjustment of the AGI distribution to changes in the long run equilibrium between the two. So, a 1 percent increase in the capital gains rate would create a 0.258 percent reduction in the AGI measure after 1.60 years, instead of one year in the case of a similar income tax rate increase.

As noted, the lagged first-difference of real wealth and the AGI distribution measures are added in ECM Specification B2. Statistically, wealth has no significant impact on the distribution of AGI in the short run. Like the capital gains rate, changes in wealth affect the distribution of AGI in the long run only. Given the value of the adjustment parameter, a 1 percent increase in wealth alters the AGI distribution with an estimated half-life of 1.16 years after a wealth change. ${ }^{18}$ Also, the value of the AGI distribution measure in the previous year has a negative effect in the current period. Finally, given an adjustment parameter value of $-0.448,44.8$ percent of the disequilibrium created by changes in any of the tax rates or wealth is eliminated one year after the change. Further, 90.7 percent is eliminated four years after any changes. ${ }^{19}$ For example, if the top capital gains tax rate increases ten percent, then 69.5 percent of the approximate 3.2 percent permanent decrease in the share of income of the top 0.5 percent takes place two years after the capital gains tax rate change.

Evaluating short run results for the alternative wealth specification, results from ECM Specification C2 appear robust with those in Specification B2. The significant short run effect of changes in the top marginal income tax rate found in the previous equation also is evident here $(-0.252)$. In addition, the transitory effect of the capital gains tax rate is economically and statistically insignificant in this specification. One difference is that the speed of adjustment is substantially higher in Specification C2 (15 percent higher). Here, the half-life of any capital gains rate change or wealth change is just under one year, and 94 percent of the long run effect on the AGI distribution measure takes place in the four years following a change in tax rates and wealth. ${ }^{20}$

\section{Importance of Wealth in Recent Tax Changes}

During the late 1980s, there occurred a large upsurge in the share of AGI reported by the top 0.5 percent of income tax filers. In 1987 however, the capital gains tax rate increased 40 percent. Based on Specification $\mathrm{B}$, this capital gains rate shock should result in a long run decrease in the share of income of the top 0.5 percent of approximately 18.5 percent. The real AGI share, however, fell just over 11 percent from 1986 through 1990. Given the long run elasticities, the share of AGI was buffered by the 12 percent growth in aggregate real wealth (or 13 percent growth of non-housing wealth) over the 1987 to 1990 period, which translates into

\footnotetext{
${ }^{18}$ In other words, half of the total effect from a change in wealth impacts the distribution of AGI after 1.16 years.

${ }^{19}$ The proportion of the gap closed after $\mathrm{n}$ periods is approximately $1-(1+\alpha)^{\mathrm{n}}$.

${ }^{20}$ Further tests examine the potential for structural breaks in the short run relationships. These tests fail to find any statistically significant break over the sample period. The results are available upon request from the authors.
} 
an approximate 7 percent increase in AGI share. Thus, as mentioned earlier, changes in real wealth partially offset impacts from the large increase in the capital gains rate.

Using evidence from the middle-to-late 1990s, one can see the possible cause for large revenue flows into the Treasury. Concurrent with the tax increase in 1993, the two measures of real wealth grew by 2.5 percent and 6 percent respectively from 1992 to 1994 . These small increases in wealth could not offset the effects of the 24.5 percent increase in the top income tax rate and one percentage point increase in the capital gains rate. ${ }^{21}$ By 1995, the situation was completely reversed. The share of AGI reported by the top 0.5 percent of households increased sharply, coinciding with a 5.2 percent and 6.4 percent increase in the wealth measures, in that one year alone. In the same year, the AGI share reported by the top 0.5 percent of all households grew 5.5 percent. Therefore, it appears that changes in real wealth and the eight percentage point reduction in the capital gains rate in the late 1990s may be responsible for the large changes in the distribution of AGI.

What does this evidence imply for policy makers? It appears that tax rates play an important role in affecting the AGI distribution, but real wealth fulfills an equally, if not more important, function. If fiscal policy is totally ineffective in altering aggregate income, lowering tax rates in a period of falling wealth, such as in 2001, may result in a declining AGI distribution measure. Conversely, the negative effect of raising tax rates on the share of AGI reported by the top 0.5 percent of households can be totally offset by robust growth in net wealth of these households in the long run. Therefore, policy makers, who are concerned about income distribution or the effect of tax rate changes on income distribution, must pay attention to expected changes in real wealth when enacting tax rate changes. Over time, the positive permanent effect of wealth increases can easily negate the negative effects of tax rate increases on the AGI share.

\section{Conclusion}

The empirical evidence presented strengthens the view that wealth has a substantial impact on the share of income earned by those in the top 0.5 percent of the AGI distribution. Positive changes in wealth can dominate the negative effects of tax rate increases on the distribution measure used here. A given percentage increase in aggregate household wealth (or non-housing wealth) and an equal percentage increase in both tax rates can actually result in a 0.3 percent increase, on average, in the share of income reported by the wealthiest households in the long run. Further, tax rates also influence the share of AGI reported by the wealthiest households in both the short run and long run. The most influential tax rate appears to be the capital gains tax rate (estimated long run elasticity of -0.42 to -0.46 ). The top marginal income tax rate plays a lesser role in the long run

\footnotetext{
${ }^{21}$ In 1993 , the top federal marginal income tax rate increased 8.6 percentage points, from 31 percent to 36 percent plus a 10 percent surcharge, making the effective top rate 39.6 percent.
} 
(estimated income tax elasticity is between 0.00 and -0.15 ). The short run evidence from the error correction models demonstrates that most of the effect of adjusting the top marginal income rate takes place in the year following the rate change. Therefore, it appears that tax rates permanently influence the share of AGI reported by the top 0.5 percent of households in the long run. Also, these permanent changes occur quickly, with 90-95 percent of these long run changes occurring within four years, and have an estimated half-life of $0.95-1.16$ years. Evidence presented in this paper suggests that if policy makers are concerned about the distribution of income, they must pay particular attention to not only macroeconomic factors, but also to either actual or expected changes in real wealth when changing tax policies.

\section{REFERENCES}

Bruce, D., M. H. Tuttle, and C. Garrison, "Changes in Income Concentration: Taxes or Macroeconomic Conditions?" Economic Inquiry, 41, 147-62, 2003.

Board of Governors of the Federal Reserve, Balance Sheet of the United States, Second Quarter, 2001.

Davis, M. and M. Palumbo, "A Primer on Economics and Time Series Econometrics of Wealth Effects," Finance and Economics Discussion Series Working Paper 2001-09, Board of Governors of the Federal Reserve System, 2001.

Dickey, D. and W. Fuller, "Likelihood Ratio Statistics for Autoregressive Time Series with a Unit Root," Econometrica, 49, 1057-72, 1981.

Feenberg, D. R. and J. M. Poterba, "Income Inequality and the Incomes of Very High-Income Taxpayers: Evidence from Tax Returns," in J. Poterba (ed.), Tax Policy and the Economy, 7, 145-77, MIT Press, Cambridge, 1993.

, "The Income and Tax Share of Very High Income Households, 1960-1995," American Economic Review, 90, 264-70, 2000.

Goolsbee, A., "Evidence on the High-Income Laffer Curve from Six Decades of Tax Reform," Brookings Papers on Economic Activity, Volume 2, 1-47, 1999.

— ,What Happens When You Tax the Rich? Evidence from Executive Compensation," Journal of Political Economy, 108, 352-78, 2000a.

, "Taxes, High-Income Executives, and the Perils of Revenue Estimation in the New Economy," American Economic Review, 90, 271-5, 2000b.

Internal Revenue Service Statistics of Income Division, Statistics of Income Bulletin, Various Issues, United States Government Printing Office, Washington DC.

Joint Committee on Taxation, Distribution of Certain Federal Tax Liabilities by Income Class for Calendar Year 2000, JCX-45-00, April 11, 2000.

—, Distribution of Certain Federal Tax Liabilities by Income Class for Calendar Year 2001, JCX-2-01, February 27, 2001.

Kennickell, A., M. Starr-McCluer, and B. Surette, "Recent Changes in U.S. Family Finances: Results from the 1998 Survey of Consumer Finances," Board of Governors of the Federal Reserve System, http://www.federalreserve.gov/pubs/oss/oss2/98/bull0100.pdf, 1998.

Klein, R., "Price Tag Call High for Bush Proposals," The Boston Globe, 3rd edition, Lexis-Nexis, http://web.lexis-nexis.com/universe/, September 15, 2004.

Kwiatkowski, D., P. C. B. Phillips, P. Scmidt, and Y. Shin, "Testing the Null Hypothesis of Stationarity Against the Alternative of a Unit Root," Journal of Econometrics, 54, 159-78, 1992.

Mehra, Y., "The Wealth Effect in Empirical Life-Cycle Aggregate Consumption Equations," Federal Reserve Bank of Richmond Economic Quarterly, 87, 45-68, 2001.

Newey, W. K. and K. D. West, "A Simple, Positive Semi-Definite, Heteroskedasticity and Autocorrelation Consistent Covariance Matrix," Econometrica, 55, 703-8, 1987.

Petrecca, L., "Candidates do the Math-Bush vs. Kerry on our Economic Future," The New York Post, all editions, Lexus-Nexis, http://web.lexis-nexis.com/universe/, August 29, 2004.

Piketty, T. and E. Saez, "Income Inequality in the United States, 1913-1918," The Quarterly Journal of Economics, 118, 1-39, 2003.

Poterba, J., "Stock Market Wealth and Consumption," Journal of Economic Perspectives, 14, 99-118, 2000 . 
Review of Income and Wealth, Series 52, Number 4, December 2006

Poterba, J. and P. Samwick, "Stock Ownership Patterns, Stock Market Fluctuations, and Consumption," Brookings Papers on Economic Activity, 2, 295-357, 1995.

Slemrod, J, "High-Income Families and the Tax Changes of the 1980s: The Anatomy of Behavioral Response," in M. Feldstein and J. Poterba (eds), Empirical Foundations of Household Taxation, University of Chicago Press, Chicago, 169-89, 1996.

, "The Fortunate 400," Office of Tax Policy Research, http://www.otpr.org/fortunate400.pdf, 2003.

Stock, J. and M. Watson, "A Simple Estimator of Cointegrating Vectors in Higher Order Integrated Systems," Econometrica, 61, 783-820, 1993. 